\title{
Popular Music and the State: The British Honours System and its Treatment of Popular Musicians
}

\author{
Emma-Jayne Reekie ${ }^{1 *}$
}

\section{University of Liverpool, UNITED KINGDOM}

\section{*Corresponding Author: ereekie@liverpool.ac.uk}

Citation: Reekie, E. J. (2019). Popular Music and the State: The British Honours System and its Treatment of Popular Musicians, Journal of Cultural Analysis and Social Change, 4(2), 12. https://doi.org/10.20897/jcasc/6356

Published: December 11, 2019

\begin{abstract}
This article examines popular musicians recognised by the British honours system within its first hundred years of operation (1917-2017). Through a statistical analysis of a unique dataset of the honoured musicians, compiled for this article, it will be asserted that to be worthy of an honour entails possessing certain nonmusical attributes including economic worth and notions of a particular type of Britishness. The increasing importance of popular music to Britain's cultural life, identity and heritage through the $20^{\text {th }}$ century and early $21^{\text {st }}$ century is vital for understanding why musicians are valued by the government through the conferral of awards. The volume of musicians awarded post-1997 will demonstrate a shift in the perception of popular music by the British government as the creative industries become increasingly important to the British economy and finally, further analysis will reveal that women are underrepresented in the honours system, a trend which reflects wider socio-cultural trends in the recognition of women artists.
\end{abstract}

Keywords: awards, popular music, cultural economy, honours system, Britishness

\section{INTRODUCTION}

"The thing about honours is that you should never ask for them, and you should never really expect them, but I think you should accept them if they are given to you" (Eliscu, 2002). This rather conformist take on the British honours system comes not from a staunch royalist but instead from Mick Jagger, lead singer of the Rolling Stones, infamous for once labelling Queen Elizabeth II the 'chief witch' (The Telegraph, 2012). A number of Jagger's contemporaries have expressed similarly surprising sentiments at their recognition by the honours system. The Who's Roger Daltry stated that it was 'really great to be honoured by my country' (BBC, 2004) and Paul McCartney declared that he was 'proud to be British' when he was awarded a knighthood in 1997 (Kelley, 2016). I use the word surprising here because these artists are among the founding fathers of 1960 s and 70 s rock music, a genre synonymous with rebellion and anti-establishment values. Therefore, as this article shows, the inclusion of these artists in the British honours system is significant and enables analysis of the honours system to illustrate how popular music's position and value within British society has shifted over time.

Examining the recognition of popular musicians by the honours system furthers our understanding of how popular music has become an important part of the cultural life and identity of Britain as it has transitioned to an economy increasingly reliant on the cultural and creative industries. The gross value added [GVA] of the creative industries increased by 53.1\% between 2010 and 2017 and generates 5.5\% of the UK economy (DCMS, 2017), and though there have been reservations about the focus on the growth in GVA in the creative economies (Banks, 2018), it must be acknowledged that since the election of New Labour in 1997 the creative industries have been a 
focus of policymakers attempting to signify cultural identity during a period of intensified globalisation (Newbigin, 2014). The music industry has an important role to play in this as, despite the initial negative effects of digitisation in the early 2000s (Jones, 2012; Moreau, 2013), it has continued to strengthen. In 2017, the UK was the second largest exporter of music in the world, contributing $£ 2.6$ billion to the British economy (UK Music, 2018). Popular music has become 'Britain's most dominant contemporary cultural export and a signifier of a confident modern identity' (Morra, 2014: 17). The British government have funded a number of projects supporting British music as an export including the Music Export Growth Scheme, which helps artists signed to independent labels by building their profiles in key overseas markets (BPI, 2017). Music tourism has also grown in the UK by 76\% between 2013 and 2016 and the popularity of attractions such as musical heritage sites and festivals added $f_{4} 4$ billion to the economy in 2016 (UK Music, 2017). The increasing profitability of the music industry and the growing importance of Britain's cultural identity, particularly in a post-Brexit world, makes an examination of the honours system, as a government pursuit, essential for understanding the government's changing view on the value of popular music in relation to British cultural identity.

This article will provide an analysis of the popular musicians who have been recognised by the honours system, when they were awarded and the reason for the award over the course of the system's first one hundred years (1917-2017). The reasons provided for giving an honour to a musician enhances our understanding of what is being valued about their contribution to culture by the awarding institution at particular times indicating which artists have been considered of most value to the British government. This article considers popular music as a commodity, the increase in popular musicians recognised by the honours system under the New Labour government and popular music's integration into British heritage. Additionally, the honours system's reflection of the British popular music canon will be explored and an examination of the gender disparities within the system will show that women musicians are less awarded than their male counterparts.

\section{THE BRITISH HONOURS SYSTEM}

The British honours system is a set of awards designed to recognise all valuable contributions to British society. As James English has argued, 'institutionally, the prize functions as a claim to authority and an assertion of that authority' (2005: 51), the honours system can therefore be understood as a way of the government honouring that which it understands as valuable to Britain. The system was introduced by King George V in 1917 as the first honour to be given to ordinary citizens in recognition of services being rendered as part of the First World War effort. The recognition of ordinary citizens, as opposed to previous honours reserved for the aristocracy, speaks to the foundation of the honours system at a time when the British royal family's position was precarious as monarchies across Europe were falling ${ }^{1}$, revolution was stirring in Russia (Walt, 1996) and socialism was gaining popularity in the UK as the working classes expanded (Thompson, 2004). Additionally, the honours system was the first set of British government awards to recognise women at all levels, a feat labelled 'a tardy recognition' even at the time (The Daily Telegraph, 1917). Since the start of the First World War, the King and his wife, Queen Mary, had taken part in a number of events interacting with the public such as inspecting troops and visiting female factory workers (BBC, 2012). The creation of the honours system was not merely recognising all classes of combatants and civilians aiding the efforts of the war but it was also part of a wider effort on behalf of the monarchy to appear dutiful to their subjects, when their royal position was the most uncertain it had been in centuries.

The four categories of the honours system that this article focuses on were all established with the founding of the system in 1917. Member of the British Empire [MBE] ranks as the lowest of the awards in recognition of 'an outstanding achievement or service to the community', Officer of the Order of the British Empire [OBE] is the next level, given for 'having a major local role in any activity'. After this, Commander of the British Empire [CBE] is given 'for having a prominent but lesser role at national level or a leading role at regional level' and the Knight/Dame of the British Empire [KBE/DBE] ranks as the highest award, given for 'a major contribution in any activity' (GOV.UK, 2019a). Anyone can nominate a living person for an honour so long as the British government can see evidence that the nominee has 'made achievements in public life' or 'committed themselves to serving and helping Britain' (GOV.UK, 2019b). Once the nomination has been made it will be passed onto an honours committee who will decide whether or not the honour should be given and what level of honour should be awarded. There are a number of honours committees who review nominations made for specific activities. The Arts and Media committee, for example, review nominated musicians, and once that committee decision has been made it will be passed onto the Main committee for further review. Each committee is made up of official members, who are senior civil servants, and independent members, who are independent of the government. An independent chairman leads each committee and a representative of 10 Downing Street is invited to attend each

${ }^{1}$ Pre-WW1, Europe had 19 monarchies and 3 republics; post-WW1, there were 14 monarchies and 16 republics (De Wijk, 2015: 101). 
committee meeting. All nominations are subject to further checks by various government departments, including HM Revenue \& Customs, to ensure that no nominee could bring the system into disrepute. Committee decisions are then reviewed by the Prime Minister who will present the approved nominations list to the ruling monarch who ultimately accepts the nominations. Successful honourees are announced twice a year, at the monarch's official birthday - the second Saturday of June - and at New Year. ${ }^{2}$ Recipients of the awards are given a physical trophy in the form of a medal and are entitled to use post-nominal letters [MBE, OBE, etc.]. In the case of receiving a knighthood or damehood, the recipient is also granted the use of the title Sir or Dame. All awardees are invited to collect their medal from a member of the royal family in a ceremony at the monarch's official London residence Buckingham Palace. The accompanying medal has come to be synonymous with the award due to media coverage reporting high profile figures receiving their honour from a member of the royal family, or being knighted with a ceremonial sword in the case of a knighthood or damehood being awarded, and then posing outside of the palace with their medals. Medals are 'objects capable of embodying or giving material shape to the honour bestowed' (English, 2005: 156), and the medal given by the honours system has not only come to visually define the system but has also become a part of popular culture. Paul McCartney and George Harrison, for example, wore their MBE medals on their infamous military regalia for the Sgt. Pepper's Lonely Hearts Club Band album front cover, further imbuing the medal with meaning beyond its original purpose.

The British honours system is ubiquitous in British society and espouses a particular British identity. The notion of Britishness, however, is one that is almost impossible to define owing to the complexity of Britain's identity as 'a multinational state with an increasingly diverse population' (Asari et al, 2008: 24) and its history of Empire and imperialism (Lloyd, 2001). The honours system's position as an award that crosses class boundaries to recognise citizens from all walks of life, a rarity in a society so heavily governed by class structures, pays tribute to the multifaceted nature of British identity. It must be noted, however, that the inclusion of the word 'Empire' within the honours system further complicates the notion of what it is to be British. The honours, as orders of the British Empire, allude to a Britain that no longer exists, but is by no means rid of the implications of its colonial past that enabled Britain's expansive Empire. There have been public calls for the system to remove mention of Empire from the awards (Davies, 2017), and Britons who have been nominated for honours have rejected them because of the continued impact caused by the actions of the British Empire (Zephaniah, 2003; Gayle, 2017). The recognition of popular musicians within the honours system can be viewed as a way for the British government to signify a particular notion of Britishness that has helped to form part of contemporary Britain's national and global identity.

\section{METHODOLOGY}

As previously noted, this article offers a statistical analysis of the popular musicians who have been awarded by the honours system. The term 'popular musician' is ambiguous and open to interpretation, so for the purpose of this research the term has been restricted to cover a person whose music, in the form of a single or album, has charted in the UK Top 100. The UK's official charts are archived, dating back to its beginning in 1952 and there are only two musicians awarded honours before this date, both of whom entered the charts at later points securing their inclusion in this research (Official Charts, 2018). The stipulation of what constitutes a popular musician has omitted some of the honours received by recipients who are considered to have made significant contributions to British popular music culture, such as radio DJ John Peel and Max Hole, CEO of Universal Music Group. Inglis' work (2010) examines the links between politics, music and celebrity through the lens of the honours system and explores what the individual musician and awarding politician can gain from the award, expanding upon existing work examining the relationship between music and politics (Bennett et al, 1993; Hague et al, 2008; Street, 1986; Street, 2003). This article builds upon Inglis' work and considers how the government's recognition of popular musicians reflects the increasing importance of popular music to Britain's cultural identity and economy. The specific focus on popular musicians does, however, limit this study. Musicians involved in musical genres not traditionally recognised in the charts, such as Channi Singh who was awarded an OBE in 2012 for services to Bhangra music, have been omitted from this research. Consequently, this work cannot be viewed as a comprehensive overview of all involved in popular music. Instead, it is an overview of those musicians who adhere to notions of mainstream popular success.

This article draws upon a unique dataset developed for this research that compiles together the 88 popular musicians awarded over the honours system first one hundred years of operation (1917-2017). The dataset [see Appendix] provides the reasons for their awards, the person's age when awarded, their gender and level of award. Analysing these characteristics has allowed for a richer insight into what the British government has valued about the musicians it has awarded. Data collection for this analysis was hindered by the lack of transparency within the

${ }^{2}$ The announcement of awards on the Monarch's official birthday and at New Year dates back to Queen Victoria's reign.

(C) 2019 by Author/s 
honours system, indeed Frey found that there was 'only partial, spotty and inconsistent evidence available from scattered sources' (2005: 6) about the conferral of honours. This led to the House of Common's Public Administration Select Committee conducting a report about the system in 2012. The report found that 'many members of the public do not view the honours system as open or fair' (House of Commons, 2012: 10) and in order to combat this perception, the government have released bi-annual lists of honours recipients and the reasons for their awards through their website since 2013. Consequently, data collection post-2012 was straightforward in comparison to the array of sources necessary to gather the same information pre-2012. Individuals awarded by the honours system have always been listed in the London newspaper The London Evening Standard, however, only the recipients' names and level of honour is listed, not the reason for their award. Furthermore, as hundreds of people are given honours in each of the bi-annual award presentations, it is difficult to locate the musicians, since all awardees are separated by level of award rather than their profession and/or reason for the award. To identify the reason given for an award, I used a variety of sources including newspaper archives and biographies and found that the reasons were always listed as "services to...". I also calculated the age recipients were when they received their awards and took note of their gender.

\section{POPULAR MUSIC AS COMMODITY: THE BEATLES}

The first two popular musicians to be awarded honours were Gracie Fields, given a CBE in 1938 for services to entertainment ${ }^{3}$, and George Formby who was awarded an OBE in 1946 for his contribution to the war effort in the capacity of an Entertainments National Service Association [ENSA] performer providing entertainment for British armed forces personnel during the Second World War. Neither Fields nor Formby were awarded for their music. Formby's performances were considered valuable insofar as they provided entertainment for soldiers living through the horror of the Second World War and Fields' honour recognised her as a member of the entertainment community at the height of her popularity in the 1930s alongside other state recognition that she was using her public position to carry out charitable work. Fields' and Formby's positions as entertainers were valued by the government not for art's sake but for the platform it allowed them to carry out charitable work. The Beatles were the next musicians to be awarded in 1965 by the Prime Minister Harold Wilson. Similar to Fields and Formby twenty years earlier, each Beatle (George Harrison, 22; John Lennon, 25; Paul McCartney, 23; Ringo Starr, 25), was honoured with an MBE for their services to export revenues, rather than, as might be expected, their music or cultural impact.

The lack of popular musicians awarded in the twenty-year gap between Formby and The Beatles is indicative of how the British government viewed popular music during that time; it was something not significant enough to acknowledge. The Beatles' honours, however, came at a time when their cultural impact was at its height. In 1964 Beatlemania and the so-called British Invasion ${ }^{4}$ were in full swing. The Beatles were dominating charts in the UK and abroad having released two studio albums, Please Please $M e$ and With The Beatles, the previous year and their first feature film A Hard Day's Night and its accompanying album in 1964. It was clear that 'commercially, as well as musically, the Beatles were fast becoming a global phenomenon' (Muncie, 2000: 40), something that British politicians could not ignore. Richard Crossman, a cabinet member in Wilson's government, wrote in his private diaries that 'he thought the decision to give the group their MBEs was justified as The Beatles were 'useful' to the government' (Cloonan, 2000: 143). Wilson's decision to award The Beatles further elevated the band to a status previously inaccessible to a pop star. The award conferred a sense of respectability on the band while also demonstrating the government's ability to understand the value - both economic and cultural - of popular music and culture to the post-war generation.

However, public reaction to The Beatles' MBEs was mixed. The New Musical Express [NME], the UK's most read weekly music magazine, celebrated The Beatles' honour by writing a letter to the band stating:

We're glad you accepted it. This means that your teenage fans, who made you, can share in the honour. And these days, when teenagers only seem to get bad publicity, how pleasant to have something good happen (Gray, 1965: 3).

Antithetically to this, however, the announcement of The Beatles' MBEs was also met with hostility and outrage. Cyril Hearn, awarded an MBE in 1944 for his bravery while deployed in Italy during the Second World War, returned his award claiming that the Queen had been 'ill-advised' in her recognition of The Beatles and that

\footnotetext{
${ }^{3}$ Fields had been previously awarded as an Officer of the Venerable Order of St. John for her charity work, a British royal order of chivalry implemented by Queen Victoria, and was later upgraded to a Damehood in 1979.

${ }^{4}$ The British Invasion was a cultural phenomenon, spearheaded by The Beatles in 1963, of exports of popular culture gaining mass popularity in the US. Bands such as The Rolling Stones, The Kinks and The Yardbirds, British film, television and fashion followed The Beatles across the Atlantic and achieved great success throughout the rest of the 1960s.
} 
it was a 'prostitution of the order' (Guardian, 1969: 20). Other members of the public at the time commented that they saw the honour as a 'political effort on the part of Wilson' and that 'it shows how little the MBE stands for these days...you'd expect them only to be awarded if they'd done something for the country and, quite honestly, I don't see what The Beatles have done' (BBC, 2015). Such statements are testament to the attitude towards popular music at this time. There was a clear generational divide between young people and their parents as a result of 'the decomposition of the pre-war working class', increased leisure opportunities and the Americanisation of British youth culture through mass mediated forms (Frith, 1983: 184). At the time of The Beatles' 1965 honours, popular music was a counterculture intended for youth; a far cry from the wide-spread, mainstream success it enjoys today. The Wilson government's decision to include popular music in the honours system helped to legitimise and place value upon popular music at a state level. By the end of the 1960s, 'pop's power was publicly realized' (Frith, 1983: 4), and arguably Wilson's recognition of The Beatles was a small part of the process that allowed popular music to surpass its status as a teenage pastime and instead become an integral part of British culture and identity. In retrospect, The Beatles are exactly the type of popular musician that the government want to be associated with through the honours system because of their musical and extra-musical impact.

John Lennon returned his MBE medal in 1969 as a symbolic form of protest, highlighting the difficulties of the state associating with popular musicians. The honours system, as an awarding body tied tightly to the state and its politics takes risk in its recognition of individuals who live within the public eye as the politics of individuals can change and adapt resulting in an opposition of views between the awarded and the awarder. Attached to Lennon's returned medal was a hand-signed note reading:

Your Majesty, I am returning my MBE as a protest against Britain's involvement in the Nigeria-Biafra thing, against our support of America in Vietnam and against 'Cold Turkey' slipping down the charts. With love, John Lennon of Bag (The Guardian, 1969).

This public and satire ridden return of an honour was embarrassing for the political establishment and the honours system. In the face of all the publicity surrounding the return of the medal, including front-page press coverage in national newspapers, the government attempted to assert its power and position with a spokesperson for Prime Minister Harold Wilson telling the press, 'that although Lennon had returned his insignia, he would not be able to divest himself of the order. He still remains an MBE.' (Evans, 1969: 1). Lennon could return his symbolic representation of the honour, but only the state could officially revoke the honour and post-nominal letters. Despite this, Lennon's act of defiance in the return of his medal did not diminish his public standing, and the symbolism deployed in his action suitably distanced Lennon from the honours system and the institution it represented. The rejection of an award 'has always been a delicate and risky manoeuvre' that has the potential to alienate the participating community, but Lennon succeeded with his rejection because he had 'managed to have already accumulated a wealth of symbolic capital' (English, 2005: 218-219) through the unexpected direction that The Beatles had taken in their musical development from pop band to serious musicians with accompanying antiestablishment actions and views by the late 1960s.

Lennon's return of his MBE medal appears to have acted as a steep learning curve for the honours system. The Beatles demonstrated how the unpredictable nature of popular music and the controlled and precise image that the honours system projects were not necessarily compatible. It took several decades for The Beatles' contemporaries to start receiving honours after Lennon's act of defiance, starting with Eric Clapton getting an OBE in 1994 for 'contribution to British life'. Like The Beatles, Eric Clapton was part of the British Invasion of the 1960s as a member of rock band The Yardbirds. After leaving the band, Clapton went on to have significant commercial success with a number of other bands, including Cream, and as a solo artist having released over twenty solo studio albums since 1970. The reason for Clapton's award is interesting since, although it appears all encompassing and therefore rather ambiguous, it can be assumed that despite Clapton's music not explicitly being recognised, he has been deemed sufficiently significant to have had an impact on the cultural life of Britain. Clapton was awarded the higher honour of a CBE in 2004 and told British newspaper The Telegraph that he would have found it hard to accept the award when he was younger but that it was now 'the icing on the cake of his career' (The Telegraph, 2004).

Ten other musicians received honours in the twenty-nine year period between The Beatles and Clapton and stand as much more traditional options for the honours system. For example, Vera Lynn, affectionally known as 'the forces' sweetheart' due to her work with ENSA entertaining troops during the Second World War, was awarded an OBE in 1969 and upgraded to a Damehood in 1975 for her services to the RAF association and charitable services. In 1980, Tommy Steele, Britain's first rock ' $n$ ' roll artist in the 1950s, was awarded an OBE for services to drama and entertainment and Cliff Richards was awarded an OBE for services to music and charity. Lynn's award is similar to that of Fields and Formby, and though both Steele and Richards can be classified as more similar to The Beatles than Fields and Formby, they nonetheless occupy a different space in the musical world. Steele and Richards both predate The Beatles and while Steele's significance in the history of popular music 
pales in comparison to The Beatles, Richards has retained relevance in the public eye. Richards' public profile is one that is less rebellious and more traditional; he frequently talks about his Christian faith and has avoided the sex, drugs and rock ' $n$ ' roll lifestyle stereotype of his counterparts. Clapton's award, therefore, seems to be indicative of a change in the government's perception of the more rebellious figures of the 1960's rock era. Despite the time that had passed since its initial success, the era had retained social relevance, beyond its economic success, that the state could not ignore.

\section{THE NEW LABOUR GOVERNMENT AND BRITISH HERITAGE}

Of all the popular musicians recognised by the honours system, $75 \%$ of these were awarded post- 1997 . The British general election of 1997 saw New Labour come into power under the leadership of Tony Blair, after eighteen years of a Conservative government. Blair was the first baby-boomer Prime Minister who, similar to Wilson, recognised the value of popular music and culture. Throughout the 1997 election, Blair focused on attracting the youth vote and capitalised on the popular Britpop movement engaging with artists like Blur, inviting frontman Damon Albarn to the houses of parliament, and attending the BRIT Awards to present a lifetime achievement award to David Bowie. The New Labour government 'attempted an unprecedented incorporation of culture into governance' (Brouillette, 2014: 1) because they recognised the economic and cultural significance that the creative industries represented. Blair said that he 'not only regards music as culturally important, but also sees the record business as more significant than mining or shipbuilding' (Clark-Meads, 1995: 40), recognising that Britain was moving from its traditional industries, which contracted under previous Tory governments, to an economy centred around the creative industries.

In 1997, at the age of 55 Paul McCartney was elevated from MBE to knighthood, Mick Jagger became a knight in 2003 at 60, Roger Daltry and Ray Davies were both given CBEs in 2004 at the ages of 60 and 59 respectively and Jimmy Page was awarded an OBE in 2005 at the age of 61. Unlike The Beatles, these artists were explicitly awarded for their 'services to music' rather than their economic value. The recognition of these artists solidifies an emergent British identity that is:

[1]ncreasingly identified in nostalgic social and cultural terms, not only with the much-celebrated legacy of the 1960s and the anti-institutional legacy of the 1970s - but with the very institutionalised cultural signifiers of Empire it is assumed to have overthrown (Morra, 2014: 170).

These bastions of rock have changed as they have aged; gaining honours in their later years demonstrates not only their continuing musical legacies but also that they have entered into a new social class of the wealthy elite that has given them time to mature and enter an institution against which their younger selves may have protested. The Who's lead singer Roger Daltry, famous for their anti-establishment anthem My Generation, said that he did not expect his CBE but accepted it despite his 'criticisms of the establishment', because of his respect for the Queen, calling her "an amazing woman" who would 'probably fall off her podium if she heard The Who's songs' (BBC, 2005). However, those within the honours system do not always necessarily see the value in those they choose to recognise. It was reported that the Queen refused to personally present Mick Jagger with his knighthood because of his anti-establishment views, alternative lifestyle and previous statements where he'd called the Queen the 'chief witch' and announced that 'anarchy is the only slight glimmer of hope' (The Telegraph, 2012). What's more, Jagger's bandmate Keith Richards publicly scorned Jagger's acceptance of the award proclaiming that he 'thought it was ludicrous to take one of those gongs from the establishment when they did their very best to throw us in jail' (BBC, 2003a). Jagger's knighthood displays a tension between traditional British authority and cultural icons that is ultimately overcome by economic value. Jagger's 2003 transformation into Sir Mick Jagger marked the end of a remarkable year for the Rolling Stones who finished a 116 date world tour playing to over 3.4 million people which grossed almost $\$ 300$ million (BBC, 2003b), a revenue and enduring popularity that arguably could not be ignored by a government promoting Britain's cultural economies.

The rising importance of the creative industries to the British economy ensured that the role of popular music evolved and became folded into the nation's heritage. As Branderello and Janssen note, 'heritage as a bridge to the past has translated into an economic resource' (2013: 3), and popular music as heritage was displayed at two major events that were witnessed on a global stage in 2002 and 2012, Queen Elizabeth II's Golden Jubilee and the London Olympics. The 2002 jubilee had a number of events over a 'jubilee weekend', which was extended to a four day public holiday for the occasion. On Monday $3^{\text {rd }}$ June a celebration of live music called the 'Party at the Palace' took place at Buckingham Palace with 12,000 guests lining the adjacent mall to watch in the presence of the royal family. One million gathered around the palace to watch on large screens, with an additional 15 million domestic viewers and 200 million worldwide (Duffett, 2004: 490). The event saw the recently knighted Cliff Richard and Paul McCartney, Dame Shirley Bassey and Eric Clapton perform alongside a number of artists who 
would go on to be honoured after the event: Ray Davies, Brian May, The Corrs, Rod Stewart, Joe Cocker and Annie Lennox. The Party at the Palace has been described as a hegemonic moment (Duffett, 2004: 494), but what was also clear at this event was that popular music was being acknowledged, on a world stage, as a valuable and defining feature of British culture and society. Britain of the new millennium, still coming to terms with its loss of empire and the accompanying power it had gathered in the previous millennium, instead focused its attention on its remaining valuable exports: its culture. Popular music's inclusion as a valuable part of modern Britain's heritage demonstrates the government's commitment to the promotion of its cultural industries as 'the heritage inevitably reflects the governing assumptions of its time and context' (Hall, 1999: 6).This was further reinforced a decade later during the 2012 London Olympics opening ceremony where British popular music was a central, narrative force of the opening and closing ceremonies, the latter being dubbed 'A Symphony of British Music', that showcased 'an elegant mash-up of British music, a rich tapestry of British culture and life' which was watched by 23 million in the UK and 750 million worldwide (Tzanelli, 2013). Similar to the Party at the Palace, there were several artists performing who had been awarded honours, including Annie Lennox, Paul McCartney and Barry and Robin Gibb of the Bee Gees. The central inclusion of popular music at these two national events intended for global consumption demonstrates the importance of popular culture, and in particular popular music, to Britain as part of its identity and as a global export. It can be deduced, therefore, that the honouring of popular musicians by the state is part of a wider acknowledgement of the importance of popular music to the UK in the twenty first century.

Popular musicians have continued to be honoured under the Conservative governments that have succeeded the Labour governments of the late 1990s and early 2000s. For example, Adele and Ed Sheeran were awarded MBEs in 2013 and 2017 respectively. Adele [aged 25] for her services to music and Sheeran [aged 26] for his services to music and charity. Alongside The Beatles, Adele and Ed Sheeran are the youngest popular musicians to ever be awarded which, considering Lennon's change of heart over the acceptance of his MBE, appears a surprising gamble for the government to take. Unlike The Beatles, both Adele and Ed Sheeran had been established artists in the music industry for at least five years before being given their awards and are pop stars rather than the rock icons The Beatles turned into. There are distinctions in popular music between rock music and pop music as both have become more established and accepted in the mainstream. Rock has become a 'cultural rival to traditional high culture' (Gracyk, 2000: 214), due partly to its social, cultural and political importance, whereas pop is still subjected to Adornian criticism of its commodified and simplistic nature (Adorno, 2001). In a similar way to The Beatles in 1965, Adele and Sheeran have both significantly contributed to the British economy through global exports of their music (Smirke, 2017) and their inclusion in the honours system at a young age suggests that, for a British government championing its cultural exports, age no longer matters in the same way when the artist in question is likely to be less controversial and has proven their ability to consistently achieve chart success on a global scale.

\section{GENDER DISPARITIES AND THE POPULAR MUSIC CANON}

Adele's 2013 honour marked her as only the $21^{\text {st }}$ female popular musician to be awarded within the honours system. Indeed, of all the popular musicians awarded by the honours system, $67 \%$ were men while only $33 \%$ were women. The lack of women popular musicians recognised by the honours system is arguably a reflection of the status of women popular musicians in British society and the British music industry. The lack of women receiving cultural prizes and awards reflects a wider disparity in rewarding women in arts and culture and is not exclusive to music (McIntyre and Cheng, 2019). Marsden found that the lack of women authors awarded in Scotland's Saltire Society Literary Awards is 'reflective of the status of women writers within Scottish literary and publishing culture more widely' (2019: 48). Similarly, 'women have never occupied an originating position in the musical canon' (Morra, 2014: 110), due mostly to the positioning of 'serious' music as a male domain which has been perpetuated by the British music press which itself is predominantly authored by male journalists (Davies, 2001). There is a perception that the male-centric consumption of popular music has been linked with other forms of social behaviour in which patriarchal discourses and practices of female exscription[...] is ingrained' (Bennett, 2013: 36). Indeed, many of the perceived social practices that accompany music fandom, such as record collecting and attending gigs, are considered to be male pursuits and even when they are practiced by women they are diminished to a lower status because they are seen as less serious when carried out by the stereotypical female fan - the teenybopper motivated by her adolescent desire rather than musical taste (Frith, 1983: 228).

Popular women musicians tend to be awarded in the honours system at a younger age than their male counterparts. Figure 1 shows the distributions of popular musicians awarded by gender and by their age, separated into decades. The age bracket of 20-29 is the only time when there are more women awarded than men, with the exception of Joy Beverley of The Beverley Sisters [a girl band popular throughout the 1950s and 1960s], who was the only person to be awarded over the age of 80 . Men are most likely to be awarded when they are aged between 


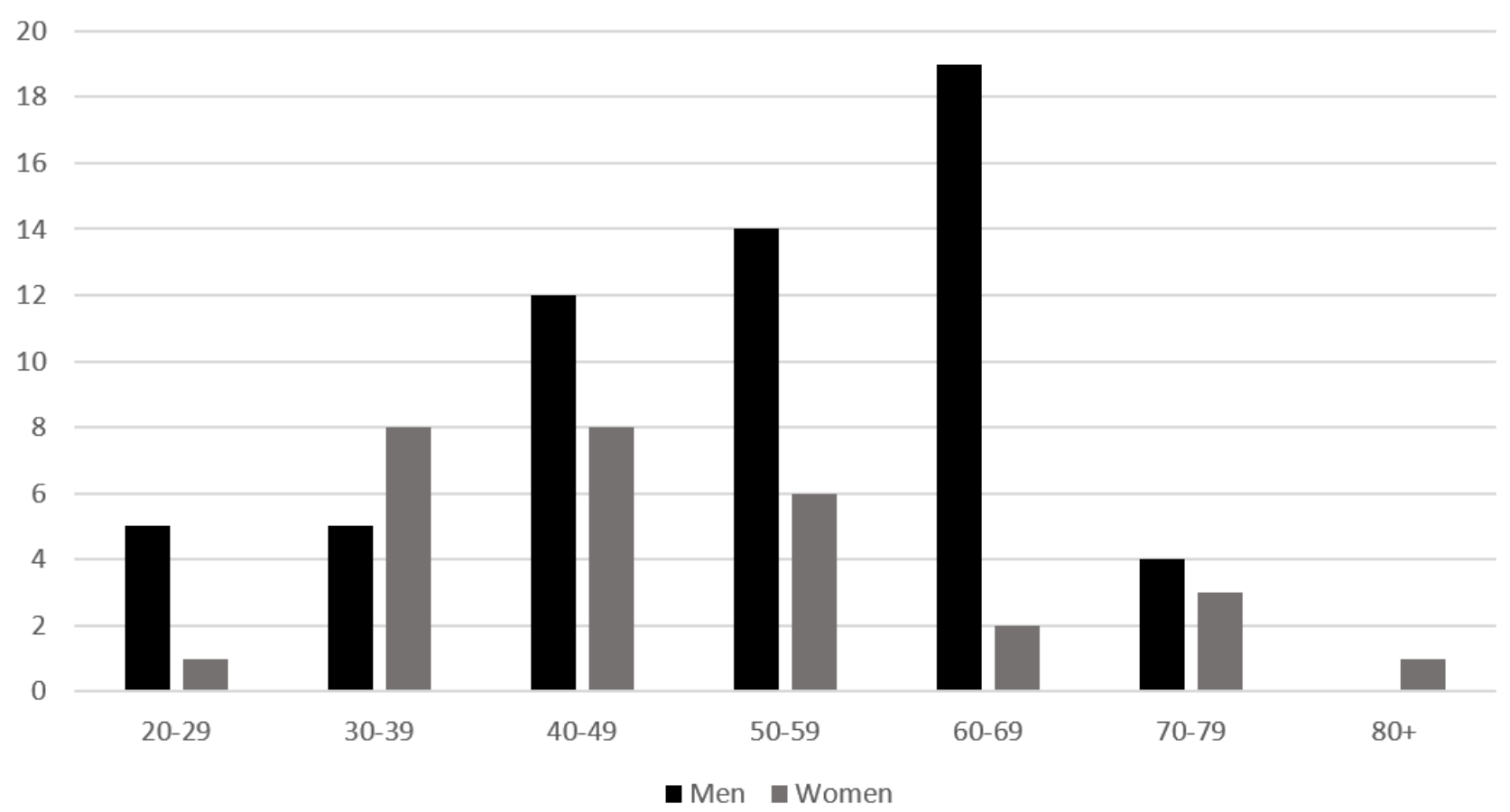

Figure 1. Men and Women Popular Musicians Awarded by Age

60 and 69 , whereas women are more likely to be awarded between the ages of 30 and 49 . The recognition of women at a younger age than men is indicative of how women are treated in the public eye as they age compared to their male counterparts. The male dominated world of popular music offers advantages to its male performers who are granted an easier succession to the echelons of the popular music canon than their female counterparts who are subjected to the 'current constellation of historical, social, cultural and biological perceptions [that] still look on women and ageing as mostly problematic, disempowering and in consequence, negatively' (Jennings, 2012: 36). Women are expected to retain their youthfulness in a way that men are not which impacts upon a woman's ability to continue performing to the same standard as when she first entered the public eye.

It should be acknowledged, however, that an honour at any level is not an innovative award; it does not recognise an artist at the outset of their career because it is not considered an artistic award. The honours are not making creative judgement, but they are recognising lasting cultural importance which is perhaps why those who have been awarded, such as Ray Davies, Graham Nash, Mick Jagger and so on, are already part of an accepted popular music canon. It also helps to explain why women are under-represented as the honours system is reflecting the values of the music industry, not contributing to it; they are merely cementing it for its own means. The notion of value is integral to both the honours system and the popular music canon, though both value different attributes. To be included in the popular music canon, a musician must display their worth through their innovation whereas to be included in the honours system, a musician must meet a different set of judgement criteria. To be awarded an honour, a popular musician must adhere to values of the canon but also demonstrate certain non-musical attributes including the ability to not bring the system into disrepute, economic worth and notions of a particular type of Britishness. This idea of being worthy of the award ties into the notion of the popular music canon, but there is also something to be said about the institution itself. Watson and Anand assert that the 'relationship between canon and institution is reflexive' and consequently that while the 'canon is legitimised by judgements made by institutions, the accuracy of canonical judgements often decides the continuing legitimacy of institutions' (2006: 54). This suggests that the process of deciding who to award an honour is somewhat of a double edged sword. The British government and monarchy, those with the final say on who is awarded an honour, need to demonstrate that they understand what is culturally important to the United Kingdom whilst simultaneously balancing which musicians meet their specific requirements.

\section{CONCLUSION}

In an interview with Smash Hits magazine in 1985, Mick Jagger was asked why he thought he had not yet been knighted. His response was "I can't think of one pop singer who's been knighted. And if they did start knighting them, I'm sure I'd be at the back of the queue." (Hibbert, 1985: 36). Bob Geldof was in fact given an honorary knighthood the following year in recognition of his charity work, but it took another decade for popular musicians to start being honoured at a regular pace. This article has shown how the recognition of popular musicians by the 
honours system, and by extension the British government and monarchy, demonstrates popular music's shifting position within British society over its first hundred years of operation, from wartime entertainment to export revenue to a culturally and economically valuable part of contemporary Britain's identity, and offers some explanation as to why this has happened. As illustrated, the popular musicians who have been honoured are those who possess certain attributes at particular times. The Beatles, among the first to be honoured, were awarded solely for their export revenues in 1965, but the increase in the amount of awards post-1997 illustrates New Labour's determination to champion the creative industries as an economic resource at the dawn of the twenty-first century as Britain left its industrial history in the previous millennium. The honours system reinforces the popular music canon; it recognises those who fit within the definition of mainstream success which allows the British government to trade off the popularity and goodwill that the British public already feels towards a particular group of musicians. This ultimately contributes to the lack of female popular musicians recognised within the honours system because it reflects an unequal popular music canon. As the music industry continues to be a significant contributor to the British economy and identity through its global exports, the musicians recognised by the honours system should continue to be examined to help us further understand which artists the British government considers to be economically and culturally valuable and important enough to be recognised as part of Britain's cultural heritage.

\section{REFERENCES}

Adorno, T. W. (2001). The Culture Industry: Selected Essays on Mass Culture. Abingdon: Routledge.

Ansari, E. M., Halikopoulou, D. and Mock, S. (2008). British National Identity and the Dilemmas of Multiculturalism. Nationalism and Ethnic Politics, 14(1), 1-28. https://doi.org/10.1080/13537110701872444

Banks, M. (2018) Creative Economies of Tomorrow? Limits to Growth and the Uncertain Future. Cultural Trends, 27(5), 367-380. https:// doi.org/10.1080/09548963.2018.1534720

BBC. (2003a). Stones Row over Jagger Knighthood. BBC News. Available at: http://news.bbc.co.uk/go/pr/fr//1/hi/entertainment/music/3290411.stm (Accessed 28 February 2017).

BBC. (2003b). Stones Tour Licks Up $\$ 300 \mathrm{~m}$. BBC News. Available at: http:// news.bbc.co.uk/1/hi/ entertainment/3244294.stm (Accessed 27 March 2019).

BBC. (2004). Rock Legend among Sussex Honours. BBC News. Available at: http://news.bbc.co.uk/1/hi/ england/southern_counties/4136135.stm (Accessed 28 February 2017).

BBC. (2005). Who Singer Daltrey Collects CBE. BBC News. Available at: http://news.bbc.co.uk/1/hi/ entertainment/4249453.stm (Accessed 2 June 2019).

BBC. (2012). King George and Queen Mary: The Royals Who Rescued the Monarchy. BBC iPlayer. January 2012. Available at: https://www.bbc.co.uk/programmes/b019fx8y (Accessed 10 September 2018).

BBC. (2015). Should The Beatles Have Been Awarded MBEs? BBC News. Available at: https://www.bbc.co.uk/ music/articles/ab4b44b7-b748-47cc-92cf-585300dcc142 (Accessed 14 September 2018).

Bennet, A. (2013). Music, Style and Aging: Growing Old Disgracefully? Philadelphia: Temple University Press.

Bennett, T., Frith, S., Grossberg, L., Shepherd, J. and Turner, G. (1993). Rock and Popular Music: Politics, Policies, Institutions. London: Routledge.

Brandellero, A. and Janssen, S. (2013). Popular Music as Cultural Heritage: Scoping Out the Field of Practice. International Journal of Heritage Studies, 20(3), 1-17. https://doi.org/10.1080/13527258.2013.779294

British Phonographic Industry. (2017). British Music Exports Rise in 2016. BPI. Available at: https://www.bpi.co.uk/news-analysis/british-music-exports-rise-in-2016/ (Accessed 15 March 2019).

Brouillette, S. (2014). Literature and the Creative Economy. Stanford: Stanford University Press. https://doi.org/ 10.11126/stanford/9780804789486.001.0001

Clark-Meads, J. (1995). 'U.K.'s Next P.M.' Vows Music Biz Respect. Billboard. August 5, (p. 40).

Cloonan, M. (2000). You Can't Do That: the Beatles, Artistic Freedom and Censorship, in I. Inglis (ed), The Beatles, Popular Music and Society: A Thousand Voices (pp. 35-52) London: Macmillan Press Ltd. https://doi.org/ 10.1007/978-1-349-62210-8_7

Davies, C. (2017). After 100 Years, is it Time to Remove 'Empire' from UK Honours System? The Guardian. 21 May. Available at: https://www.theguardian.com/politics/2017/may/21/after-100-years-is-it-time-toremove-empire-from-uk-honours-system (Accessed 1 June 2019).

Davies, H. (2001). All Rock and Roll is Homosocial: the Representation of Women in the British Rock Music Press. Popular Music, 20(3), 301-319. https://doi.org/10.1017/S0261143001001519

De Wijk, R. (2015). Power Politics: How China and Russia Reshape the World. Amsterdam: Amsterdam University Press. https://doi.org/10.2307/j.ctt1970542

Department for Digital, Culture, Media \& Sport (DCMS). (2017). DCMS Sectors Economic Estimates 2017 (provisional): Gross Value Added. British Government. Available at: https://www.gov.uk/government/ statistics/dcms-sectors-economic-estimates-2017-gva (Accessed 20 February 2019). 
Duffett, M. (2004). A "Strange Blooding in the Ways of Popular Culture"? Party at the Palace as Hegemonic Project. Popular Music and Society, 27(4), 489-506. https://doi.org/10.1080/0300776042000264685

Eliscu, J. (2002). Mick Jagger Knighted. Rolling Stone. Available at: https://www.rollingstone.com/music/musicnews/mick-jagger-knighted-2-237658/ (Accessed 27 February 2019).

English, J. F. (2005). The Economy of Prestige: Prizes, Awards, and the Circulation of Cultural Value. Cambridge: Harvard University Press. https://doi.org/10.4159/9780674036536

Frith, S. (1983). Sound Effects: Youth, Leisure and the Politics of Rock'n'Roll. London: Constable.

Gayle, H. (2016). Why I Showed the Red Card to an MBE. The Guardian. 15 August. Available at: https://www. theguardian.com/commentisfree/2016/aug/15/howard-gayle-mbe-liverpool-first-black-footballer (Accessed 1 June 2019).

GOV.UK. (2019a). Nominate Someone for an Honour or Award: Types of Honours and Awards. GOV.UK. Available at: https://www.gov.uk/honours/types-of-honours-and-awards (Accessed 1 June 2019).

GOV.UK. (2019b). Nominate Someone for an Honour or Award: Overview. GOV.UK. Available at: https:/ /www.gov.uk/honours (Accessed 1 June 2019).

Gracyk, T. (1999). Valuing and Evaluating Popular Music. The Journal of Aesthetics and Art Criticism, 52(2), 205-220. https://doi.org/10.2307/432313

Gray, A. (1965). Salute to the MBEeatles. New Musical Express. 18 June. p. 3.

Griffith, N. (2015). Books About Women Don't Win Big Awards: Some Data. Nicola Griffith. Available at: https://nicolagriffith.com/2015/05/26/books-about-women-tend-not-to-win-awards/ (Accessed 5 January 2019).

Hague, S., Street, J., and Savigny, H. (2008). The Voice of the People? Musicians as Political Actors. Cultural Politics, 4(1), 5-24. https:// doi.org/10.2752/175174308X266370

Hall, S. (1999). Whose Heritage? Un-Settling 'The Heritage', Re-imagining the Post-Nation. Third Text, 13(49), 313. https://doi.org/10.1080/09528829908576818

Hibber, T. (1985). If You Don't Know Who This Bloke Is, Ask Your Parents. Smash Hits. 14 February, (p. 36).

House of Commons Public Administration Select Committee, 2012. The Honours System. London: House of Commons. Available at: https://www.publications.parliament.uk/pa/cm201213/cmselect/cmpubadm/19/ 19.pdf. (accessed 24 February 2017).

Inglis, I. (2010). The Politics of Stardust or the Politics of Cool: Popular Music and the British Honours System. International Review of the Aesthetics and Sociology of Music, 41(1), 51-71. Retrieved from http:/ /www.jstor.org/ stable/27822863

Jennings, R. (2012). It's All Just a Little Bit of History Repeating: Pop Stars, Audiences, Performance and Ageing - Exploring the Performance Strategies of Shirley Bassey and Petula Clark, in R. Jennings and A. Gardner (eds.), 'Rock On': Women, Ageing and Popular Music (pp. 35-51). Farnham: Ashgate Publishing Limited.

Jones, M. (2012). The Music Industries: From Conception to Consumption. Basingstoke: Palgrave Macmillan.

Kelley, K. (2016). The Day Paul McCartney was Knighted. Ultimate Classic Rock. Available at: http:/ / ultimateclassicrock.com/paul-mccartney-knighted/ (Accessed 27 February 2019).

Lloyd, T. (2001). Empire: The History of the British Empire. London: Hambledon and London.

Marsden, S. (2019). Why Women Don't Win Literary Awards: The Saltire Society Literary Awards and Implicit Stereotyping. Women: A Cultural Review, 30(1), 43-65. https://doi.org/10.1080/09574042.2018.1561047

McIntyre, N., and Cheng, O.C. (2019). Is Age Just a Number? Oscar Winners re Getting Older, Analysis Reveals. The Guardian. 22 February. Available at: https:/ /www.theguardian.com/film/2019/feb/22/is-age-just-anumber-oscar-winners-are-getting-older-analysis-reveals (Accessed 5 September 2019).

Moreau, F. (2013). The Disruptive Nature of Digitization: The Case of the Recorded Music Industry. International Journal of Arts Management, 15(2), 18-31.

Morra, I. (2014). Britishness, Popular Music, and National Identity: the Making of Modern Britain. Oxon: Routledge. https://doi.org/10.4324/9780203503218

Muncie, J. (2000). The Beatles and the Spectacle of Youth, in I. Inglis (ed.), The Beatles, Popular Music and Society: A Thousand Voices (pp. 35-52). London: Macmillan Press Ltd. https://doi.org/10.1007/978-1-349-62210-8_3

Newbigin, J. (2014). What is the Creative Economy? British Council. Available at: https:// creativeconomy. britishcouncil.org/guide/what-creative-economy/ (Accessed 2 March 2019).

Official Charts. (2018). Archives. Official Charts. Available at: http://www.officialcharts.com/archive/ (Accessed 10 September 2018).

Smirke, R. (2017). Ed Sheeran and Adele Help Propel British Music Exports 11 Percent to $\$ 480$ million. Billboard. Available at: https:/ /www.billboard.com/articles/business/7957561/british-music-exports-bpiglobal-figures-2016 (Accessed 26 March 2019).

Street, J. (1986). Rebel Rock: The Politics of Popular Music. Oxford: Blackwell. 
Street, J. (2003). Fight the Power: The Politics of Music and the Music of Politics. Government and Opposition, 38(1), 113-130. https:// doi.org/10.1111/1477-7053.00007

Street, J. (2005). 'Showbusiness of a Serious Kind': A Cultural Politics of the Arts Prize. Media, Culture and Society, 27(6), 819-840. https:// doi.org/10.1177/0163443705057672

The Daily Telegraph. (1917). Ladies of Chivalry. A Tardy Recognition. The Daily Telegraph. 22 June, (p. 3).

The Guardian. (1969). Hero Wants His Medal Back Now. The Guardian. 27 November, (p. 1).

The Guardian. (1969). John Lennon Protests - and Returns MBE. The Guardian. 26 November, (p. 20).

The Telegraph. (2004). Ex-Rebel Clapton Receives his CBE. The Telegraph. Available at: http://www.telegraph. co.uk/news/uknews/1475787/Ex-rebel-Clapton-receives-his-CBE.html (Accessed 2 March 2017).

The Telegraph. (2012). Why The Queen 'Refused to Hand Mick Jagger a Knighthood'. The Telegraph. 11 July. Available at: http://www.telegraph.co.uk/news/uknews/theroyalfamily/9391107/Why-the-Queen-refusedto-hand-Mick-Jagger-a-knighthood.html (Accessed 27 February 2017).

Thompson, N. (2007). Socialist Political Economies and the Growth of Mass Consumption in Britain and the United States, 1880 to 1914. Review of Radical Political Economics, 39(2), 230-256. https://doi.org/10.1177\%2F0486613407302485

Tzanelli, R. (2013). Olympic Ceremonialism and the Performance of National Character: From London 2012 to Rio 2016. London: Palgrave Macmillan. https://doi.org/10.1057/9781137336323

UK Music. (2017). Wish You Were Here 2017: The Contribution of Live Music to the UK Economy. UK Music. Available at: https://www.ukmusic.org/assets/general/Report_WYWH_17.pdf (Accessed 14 March 2019).

UK Music. (2018). Measuring Music: 2018 Report. UK Music. Available at: https://www.ukmusic.org/assets/ general/UK_Music_Measuring_Music_2018.pdf (Accessed 12 March 2019).

Walt, S. M. (1996). Revolution and War. New York: Cornell University Press.

Watson, M. R. and Anand, N. (2006). Award Ceremony as Arbiter of Commerce and Canon in the Popular Music Industry. Popular Music, 25(1), 41-56. https:/ / doi.org/10.1017/S0261143005000747

Zephaniah, B. (2003). 'Me? I thought, OBE me? Up Yours, I thought'. The Guardian. 27 November. Available at: https:/ /www.theguardian.com/books/2003/nov/27/poetry.monarchy (Accessed 1 June 2019). 


\section{APPENDIX}

Popular Musicians Awarded by the Honours System 1917-2017

\begin{tabular}{|c|c|c|c|c|}
\hline $\begin{array}{l}\text { Year } \\
\text { Awarded }\end{array}$ & Name and Level of Award & Reason for Award & $\begin{array}{l}\text { Age When } \\
\text { Awarded }\end{array}$ & Gender \\
\hline $1938 / 1979$ & Gracie Fields, CBE/DBE & Services to entertainment & $40 / 81$ & Female \\
\hline 1946 & George Formby, OBE & Contribution to the war effort & 42 & Male \\
\hline 1965 & John Lennon, MBE & Export revenues & 25 & Male \\
\hline $1965 / 1997$ & Paul McCartney, MBE/KBE & Export revenues/Services to music & $23 / 55$ & Male \\
\hline 1965 & George Harrison, MBE & Export revenues & 22 & Male \\
\hline 1965 & Ringo Starr, MBE & Export revenues & 25 & Male \\
\hline 1965/1996 & Frankie Vaughan, OBE/CBE & Youth services & 37 & Male \\
\hline $1969 / 1975$ & Vera Lynn, OBE/DBE & $\begin{array}{l}\text { Services to the RAF association and other } \\
\text { charities/Charitable services }\end{array}$ & $48 / 54$ & Female \\
\hline 1970 & Kenny Lynch, OBE & Services to entertainment & 32 & Male \\
\hline 1979 & Olivia Newton-John, OBE & Services to charity and the entertainment industry & 31 & Female \\
\hline $1979 / 1997$ & Cleo Laine, OBE/DBE & Services to music & $52 / 70$ & Female \\
\hline 1980/1996 & Cliff Richard, OBE/KBE & Services to music and charity & $40 / 55$ & Male \\
\hline 1980 & Tommy Steele, OBE & Services to drama and entertainment & 44 & Male \\
\hline 1986 & Bob Geldof, KBE (Honorary) & In recognition of charity work & 35 & Male \\
\hline 1991 & Chris Barber, OBE & Services to music & 61 & Male \\
\hline 1993 & Tim Finn, OBE & Contribution to music & 41 & Male \\
\hline 1993 & Neil Finn, OBE & Contribution to music & 37 & Male \\
\hline $1994 / 2004$ & Eric Clapton, OBE/CBE & Contribution to British life/Services to music & $49 / 59$ & Male \\
\hline $1994 / 2000$ & Shirley Bassey, CBE/DBE & Services to music/Services to entertainment & $57 / 63$ & Female \\
\hline 1995 & Elaine Paige, OBE & Contributions to musical theatre & 47 & Female \\
\hline 1996/1998 & Elton John, CBE/KBE & Services to music and charitable services & $49 / 51$ & Male \\
\hline 1996 & Van Morrison, OBE & Services to music & 51 & Male \\
\hline 1998 & Petula Clark, CBE & Services to music & 66 & Female \\
\hline 1999 & David Essex, OBE & Outstanding services to music & 52 & Male \\
\hline $1999 / 2006$ & Tom Jones, OBE/KBE & Services to music & $59 / 66$ & Male \\
\hline 1999 & Dusty Springfield, OBE & Services to the music industry & 60 & Female \\
\hline 2000 & Mark Knopfler, OBE & Services to music & 51 & Male \\
\hline $2000 / 2009$ & Courtney Pine, OBE/CBE & Services to jazz music & $36 / 45$ & Male \\
\hline 2000 & Lonnie Donegan, MBE & Services to pop music & 69 & Male \\
\hline 2000 & Noddy Holder, MBE & Services to show business & 54 & Male \\
\hline 2000 & Lulu, OBE & Services to the British music industry & 52 & Female \\
\hline 2001 & Daniel O’Donnell, MBE & Services to the music industry and charity & 40 & Male \\
\hline 2001 & Acker Bilk, MBE & Services to the music industry & 72 & Male \\
\hline 2001 & Joan Armatrading, MBE & Services to music & 51 & Female \\
\hline $2002 / 2017$ & Sade Adu, OBE/CBE & Services to music & 43 & Female \\
\hline 2002 & Barbara Dickinson, OBE & Services to music and drama & 55 & Female \\
\hline 2002 & Gordon Sumner (Sting), CBE & Services to music & 51 & Male \\
\hline 2003 & David Gilmour, CBE & Services to music & 57 & Male \\
\hline 2003 & Jools Holland, OBE & Services to music industry & 45 & Male \\
\hline 2003 & Mick Jagger, KBE & Services to music & 60 & Male \\
\hline 2003 & Gerry Marsden, MBE & Services to charity & 61 & Male \\
\hline 2003 & Gary Brooker, MBE & Services to charity & 58 & Male \\
\hline 2003 & Errol Brown, MBE & Services to popular music & 60 & Male \\
\hline 2004 & Roger Daltrey, CBE & Services to music, entertainment industry and charity & 60 & Male \\
\hline $2004 / 2017$ & Ray Davies, CBE/KBE & Services to the music industry/Services to the arts & $59 / 72$ & Male \\
\hline 2004 & Barry Gibb, CBE & Services to music & 55 & Male \\
\hline 2004 & Robin Gibb, CBE & Services to music & 55 & Male \\
\hline 2004 & Maurice Gibb, CBE & Services to music & 60 & Male \\
\hline 2004 & Brian Bennett, OBE & Services to music & 64 & Male \\
\hline 2004 & Bruce Welch, OBE & Services to music & 63 & Male \\
\hline 2005 & Jimmy Page, OBE & Services to music industry & 61 & Male \\
\hline 2005 & Brian May, CBE & Services to music industry and charity & 58 & Male \\
\hline 2005 & Andrea Corr, MBE (honorary) & Services to music and charity & 31 & Female \\
\hline 2005 & Caroline Corr, MBE (honorary) & Services to music and charity & 32 & Female \\
\hline
\end{tabular}


Journal of Cultural Analysis and Social Change, 4(2), 12

\begin{tabular}{|c|c|c|c|c|}
\hline $\begin{array}{l}\text { Year } \\
\text { Awarded }\end{array}$ & Name and Level of Award & Reason for Award & $\begin{array}{l}\text { Age When } \\
\text { Awarded }\end{array}$ & Gender \\
\hline 2005 & Jim Corr, MBE (honorary) & Services to music and charity & 35 & Male \\
\hline 2005 & Sharon Corr, MBE (honorary) & Services to music and charity & 41 & Female \\
\hline 2005 & John Mayall, OBE & Services to British music & 72 & Male \\
\hline 2005 & Midge Ure, OBE & Services to music and charity & 52 & Male \\
\hline 2006 & $\begin{array}{l}\text { Paul Hewson (Bono), KBE } \\
\text { (honorary) }\end{array}$ & Services to music and humanitarian causes & 46 & Male \\
\hline 2006 & Babette Beverley, MBE & Services to music & 79 & Female \\
\hline 2006 & Joy Beverley, MBE & Services to music & 82 & Female \\
\hline 2006 & Teddie Beverley, MBE & Services to music & 79 & Female \\
\hline 2006 & Eddi Reader, MBE & Services to music & 47 & Female \\
\hline 2007 & Beverley Knight, MBE & Services to music & 34 & Female \\
\hline 2007 & Joe Cocker, OBE & Services to music & 63 & Male \\
\hline 2007 & Rod Stewart, CBE & Services to music & 62 & Male \\
\hline 2008 & Kylie Minogue, OBE & Services to music & 40 & Female \\
\hline 2009 & Robert Plant, CBE & Services to music & 61 & Male \\
\hline 2009 & John Martyn, OBE & Services to music & 60 & Male \\
\hline 2010 & Rick Parfitt, OBE & Services to music and charity & 62 & Male \\
\hline 2010 & Francis Rossi, OBE & Services to music and charity & 61 & Male \\
\hline 2010 & Graham Nash, OBE & Services to music and charitable services & 68 & Male \\
\hline 2010 & Jet Harris, MBE & Services to music & 71 & Male \\
\hline 2010 & John Cale, OBE & Services to music and the arts & 68 & Male \\
\hline 2011 & Bryan Ferry, CBE & Services to music & 66 & Male \\
\hline 2011 & Annie Lennox, OBE & Services to charity & 56 & Female \\
\hline 2012 & Gary Barlow, OBE & Services to music and charity & 41 & Male \\
\hline 2013 & Adele Adkins, MBE & Services to music & 25 & Female \\
\hline 2013 & PJ Harvey, MBE & Services to music & 43 & Female \\
\hline 2014 & Katherine Jenkins, OBE & Services to music and charity & 32 & Female \\
\hline 2014 & Eliza Carthy, MBE & Services to folk music & 38 & Female \\
\hline 2014 & Cerys Matthews, MBE & Services to music & 45 & Female \\
\hline 2016 & Damon Albarn, OBE & Services to music & 47 & Male \\
\hline 2016 & Clifford Price (Goldie), MBE & Services to music and young people & 50 & Male \\
\hline 2017 & Marty Wilde, MBE & Services to popular music & 78 & Male \\
\hline 2017 & Ed Sheeran, MBE & Services to music and charity & 26 & Male \\
\hline 2017 & Emeli Sande, MBE & Services to music & 30 & Female \\
\hline 2017 & Sandie Shaw, MBE & Services to music & 70 & Female \\
\hline
\end{tabular}

